\title{
The Impact of Service Quality on Customer Satisfaction: A Study on Higher Education Students in Timor-Leste
}

\author{
Cornelia F. da Costa Ferreira ${ }^{1}$, Mesis Kana Djo ${ }^{2}$, Jorge Ribeiro Freitas ${ }^{3}$, Marcos Taec Abi $^{4}$ \\ ${ }^{1,2}$ School of Tourism and Hospitality, Dili Institute of Technology, Timor-Leste \\ ${ }^{3}$ School of Business and Management, Dili Institute of Technology, Timor-Leste \\ ${ }^{4}$ Centre for Language Studies Dili Institute of Technology, Timor-Leste \\ Email: corneliafenidcostaferreira@gmail.com; mesis.kanadjo@gmail.com; freitasjorger@gmail.com; marcostaecabi040585@gmail.com
}

\begin{abstract}
This research aims to test and assess the influence of service quality on customer satisfaction. Students from Hotel Management Department, Dili Institute of Technology (DIT), Timor-Leste were used as research respondents; while data collection and analysis used questionnaires and SMART-PLS 3.1 respectively. The result shows that service quality influence positively and significantly on customer satisfaction. This research can help industries to improve their service quality to raise customer satisfaction, leading to improve their performance.
\end{abstract}

Keywords: Service quality; customer satisfaction, Timor-Leste.

\section{Introduction}

Customer satisfaction is an important factor for profit and nonprofit organizations because satisfaction is an indicator for the successfulness of an organization (Tongshinen et al. 2018). Customer Satisfaction is an evaluation for the customers about a product or a service according to their perception or the difference between expectations and what they get (Parasuraman, Zeithaml and Berry, 1994; Mbama and Ezepue, 2018).

Customer satisfaction is influenced by service quality (Jiang and Zhang, 2016). Service quality is considered as the difference between the service that customers want to get and the service that they receive (Parasuraman, Zeithaml and Berry, 1988; Farooq et al., 2018). Gilbert and Cleopatra Veloutsou (2016) considered service quality as a factor that helps an organization to achieve its objectives. Thus, service quality has to be based on customer expectations in order to be satisfied through the product or the service that they use (Spyridou, 2017), as it can give a direct impact towards customer satisfaction. Satisfied customers will continue to buy the product as the company may get a long term profit (Wilkins et al, 2007; Lam and Burton, 2006).

Numerous studies had been done, the results showed that service quality has a positive and significant impact on customer satisfaction (Keshavarz and Jamshidi, 2018; Saldanha et al., 2018; Flores, Saldanha and Vong, 2020; Borishade et al., 2021) because if customers feel that an organization offers good service quality, then they will be happy and will return to buy the product/ service offered (Khoo, Ha and McGregor, 2017; Rua, Saldanha and Amaral, 2020; Annamdevula and Raja Shekhar Bellamkonda, 2016; Borishade et al., 2021). However, study from Famiyeh, Kwarteng and Asante-Darko, (2018) showed that service quality had partial influenced on customer satisfaction due to the reliability dimension in the service quality is not related to customer satisfaction. In addition, most existing studies were carried out in developed countries, but still limited undertaken in emerging countries which its service industries were under developing stage.

Inconsistency results of the previous studies occurred due to types, resources, and environment of industries. Moreover, "only some resources may lead to sustained competitive advanced as they may have differential effects on actual performance" (DeSarvo, et al., 2015). In addition, "different industries face different competitive forces and thus they perform differently" (Rompho, N.,2015,59). Therefore, studies should be done continuously to discover appropriate indicators for every industry. This research aims to test and analyze the influence of service quality on student's satisfaction.

\section{Theoretical Framework}

\subsection{Service Quality}

According to Javadin (2003; as in Mahmudi \& Abdoli, 2016), Service is an activity which is presented from one party to another. Moreover, it is also defined as "an intangible activity or profit offered from one party to another which does not lead to ownership (Cotler, 2000,321; as in Mahmudi \& Abdoli, 2016,791). On the other hand, "quality means the ability of given product to meet the target produced by the minimum possible cost"(Mahmudi and Abdoli, 2016, 790).

Elisabet et al. $(2019,173)$ define service quality as the way in which clients are served in an organization which could be good or poor. Good service will give good benefits 
to the company. When customers do not satisfy with a product or a service, they will not buy the product offered for the second time. Service quality has a significant impact on customer loyalty through customer satisfaction (Annamdevula and Raja Shekhar Bellamkonda, 2016; Borishade et al., 2021).

\subsection{Customer Satisfaction}

Customer satisfaction is the perception of customers about products or services that are based on their expectations (Dominici and Guzzo, 2010; Sangpikul, 2018; Boonlertvanich, 2019). Customer satisfaction is the expectations of each person for the goods that he/she buys or the service that he/she gets (Carranza, Díaz and MartínConsuegra, 2018).

According to Gunarathne (2014; as in Tongshinen, et al.,2018), Customer satisfaction is expressed by the concordance level between the expected and experienced. Customer satisfaction makes the customers have a strong relationship with a company (Miranda, Tavares and Queiró, 2018), and so it can make customers own the loyalty concerning the products or services from a company (Chen, 2012). This statement is supported by Ranabhat (2018) who states that customer satisfaction becomes the first key indicator for business. Therefore, companies need to pay attention to customers' needs. Customer satisfaction can also look at the value of the products or services offered by an industry (Kaura, Prasad and Sharma, 2015; Babin et al., 2019).

\section{Conceptual Model and Hypothesis}

Service quality is an antecedent variable for customer satisfaction. Service quality is considered as a factor that the company can achieve its objectives about customer satisfaction within the industry (Gilbert and Cleopatra Veloutsou, 2016). Customer satisfaction is related to the comparison between customers' expectations and the real experience of a product or a service (Boonlertvanich, 2019). Therefore, companies need to improve their service quality based on customer needs (Boonlertvanich, 2019). Numerous studies revealed that service quality has a direct impact on customer satisfaction (Annamdevula and Raja Shekkar Bellamkonda, 2016; Sriyalatha and Appuhamilage, 2019; Borishade et al., 2021).

$\mathrm{H}$ : Service quality has a positive impact on customer satisfaction.

\section{Research Methodology \\ 4.1 Population, Sample, and Data Collection}

This research was administered within one month at the Dili Institute of Technology (DIT). The total population of the study were 71 people who studied in the Hotel Management Department at Dili Institute of Technology in the academic year 2017 to 2020 . This number of students was taken as a sample because of the minimum number of students. Therefore, all students were considered as the sample for this research. The questionnaire was adopted from previous authors (Parasuraman et al., 1988 \& 1994; Stavkova et al, 2008).

\subsection{Technique of Data Analysis}

This research used the quantitative inferential method to test the relationship between indicators (outer model measurement) and variables (inner model measurement). In this research, Smart-PLS 3.0 was used as an instrument to analyze both outer model and inner model data because this instrument can be used to test multiple variables, reflective/informative indicators, small sample with a minimum number of 30 (Hair et al., 2014).

In the outer model measurement test, it will look at the validity and reliability of the relationship between indicators and variables. There are two types of validity tests such as convergent validity and discriminant validity. Convergent validity usually uses the parameter of loading indicator or outer loading (OL) with the value of larger than 0.7 , and the value of average variance extracted (AVE) is larger than 0.5.

An indicator is valid when the OL value is above the threshold value of 0.7 and the AVE value is larger than 0.5 (Hair et al., 2014). Discriminant validity usually uses Fornell-Larcker (FL) criterion parameter and heterotraitmonotrait (HTMT). FL criterion is the value of a root square item (e.g. $\left.S_{11}\right)$ for its item $\left(S_{11}\right)$ larger than the value of other root square items (Hair et al., 2014). On the other hand, an item or indicator can be valid if the HTMT value is smaller than 0.90 (Henseler et al., 2015). The hypothesis test uses a path coefficient that more on the $\mathrm{T}$ and $\mathrm{P}$-value. The relationship between variables can be significant if the $\mathrm{T}$ value is larger than 1.96 and $\mathrm{P}$-value is smaller than 0.05 (Hair et al., 2017).

\section{Results and Discussion \\ 5.1. Validity and Reliability Test}

Two types of validity test namely convergent validity and discriminant validity. Convergent validity uses two parameters namely outer loading (OL) with the threshold value larger than 0.7 and average variance extracted (AVE) with the minimum allowable value of 0.5 (Hair et al., 2014 ho Hair et al., 2017).

The research results show that the item of OL value from tangible dimension $\left(\mathrm{SQ}_{1}\right)$, Reliability $\left(\mathrm{SQ}_{21}\right)$, customer satisfaction $\left(\mathrm{CS}_{1}\right)$ are well below the minimum threshold value of 0.7 which leads to influence the content validity 


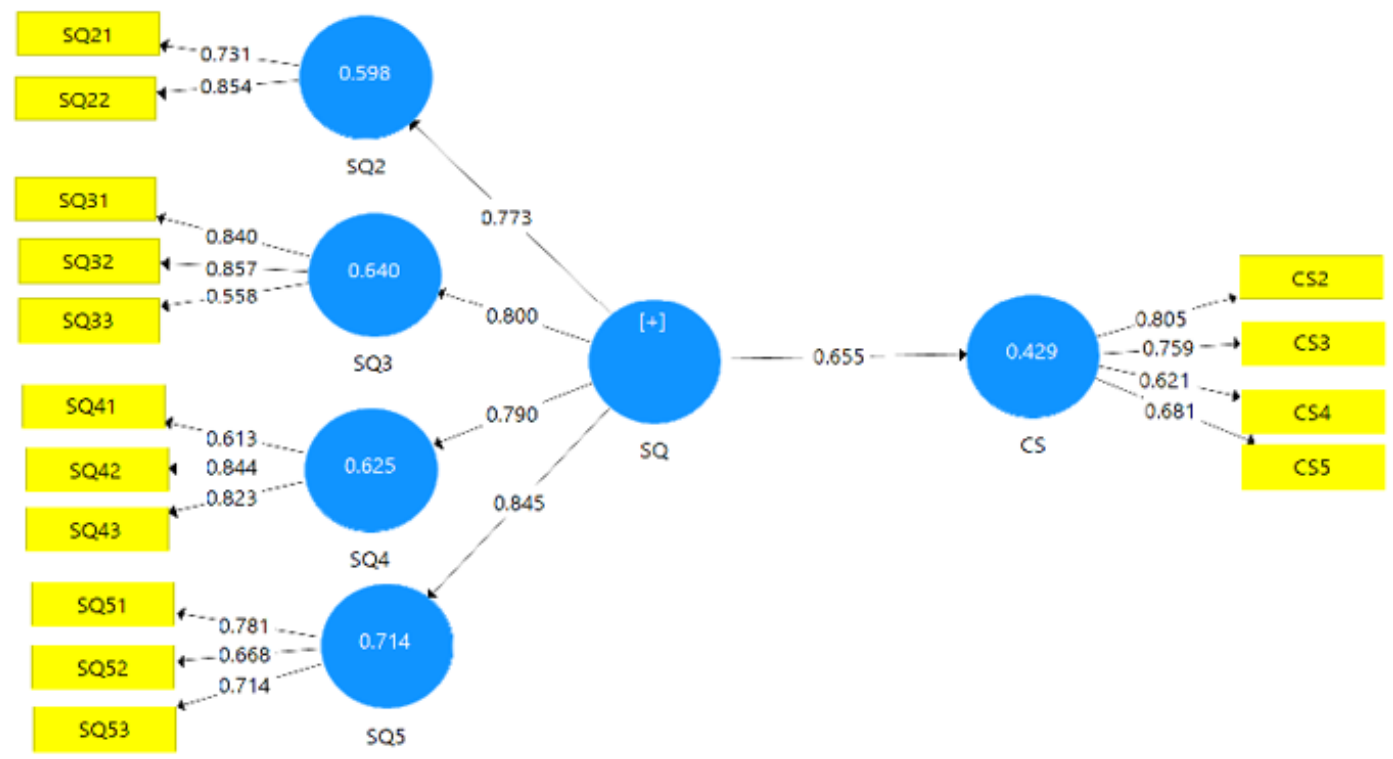

Figure 1. Outer Loading for Convergent Validity

(AVE value). According to Hair et al. (2014), if the OL value is smaller than 0.5 which influences content validity (AVE value), these items can be eliminated from the model. In general, the OL values of items are larger than 0.7 (Figure 1). Nonetheless, for exploratory research, the OL minimum allowable value of OL can be 0.6 (Hair et al., 2014). On the other hand, the value of average variance extracted (AVE) is larger than 0.5 (Table III), therefore all items are valid to test the relationship between variables (inner model).

The discriminant validity test uses two parameters namely Fornell-Larcker Criterion (FLC) and heterotraitmonotrait (HTMT). From the FLC side, the values for all items are valid for use to test the relationship between variables (inner model) in this research (Table I). This is based on the recommended principles by Hair et al. (2014) about discriminant validity test using Fornell-Larcker Criterion.

Table I. Fornell-Larcker Criterion for Discriminant Validity

\begin{tabular}{cccccc|} 
Item & SQ2 & SQ3 & SQ4 & SQ5 & CS \\
SQ2 & 0.794 & & & & \\
SQ3 & 0.510 & 0.878 & & & \\
SQ4 & 0.531 & 0.467 & 0.767 & & \\
SQ5 & 0.469 & 0.620 & 0.581 & 0.722 & \\
CS & 0.534 & 0.490 & 0.510 & 0.522 & 0.720 \\
\hline
\end{tabular}

Table II also indicates about discriminant validity test using the HTMT parameter. Through this, all HTMT values are smaller than 0.90 , and so all items are valid to be used to test the relationship between variables (Henseler, Ringle and Sarstedt, 2015).
Table II. Heterotrait-Monotrait Ratio (HTMT) for Discriminant Validity

\begin{tabular}{|ccccc|}
\hline Item & SQ2 & SQ3 & SQ4 & SQ5 \\
\hline SQ3 & 0.829 & & & \\
\hline SQ4 & 0.862 & 0.697 & & \\
\hline SQ5 & 0.853 & 0.888 & 0.885 & \\
\hline CS & 0.859 & 0.672 & 0.776 & 0.887 \\
\hline
\end{tabular}

Reliability items from all construct tests using Cronbach's alpha (CA) and composite reliability (CR). The results of this research as shown in Table III indicates that $\mathrm{CA}$ value from all items is larger than 0.6 and all CR values are larger than 0.7. Thus, according to Hair et al. (2014) and Hair et al. (2017), all items are reliable to test the relationship between variables (inner model).

Table III. Reliability and Validity

\begin{tabular}{|ccc|cc|}
\hline Item & CA & CR & AVE & Item \\
\hline SQ2 & 0.625 & 0.772 & 0.631 & SQ2 \\
\hline SQ3 & 0.705 & 0.871 & 0.772 & SQ3 \\
\hline SQ4 & 0.745 & 0.809 & 0.589 & SQ4 \\
\hline SQ5 & 0.644 & 0.764 & 0.521 & SQ5 \\
\hline CS & 0.693 & 0.811 & 0.519 & CS \\
\hline
\end{tabular}

\subsection{Hypothesis Test}

The hypothesis of this research is to see the significant influence of service quality (SQ) on customer satisfaction (CS). The research result as shown in Table IV that SQ influences positively and significantly $\mathrm{CS}$; the $\mathrm{T}$ value (7.824) is higher than 1.96 and the P-value (0.000) is lower than 0.05 . Thus, service quality has a positive influence and 
Table IV. Path Coefficient for the Hypothesis Test

\begin{tabular}{|cccccc|} 
& $\begin{array}{c}\text { Original } \\
\text { Sample (O) }\end{array}$ & $\begin{array}{c}\text { Sample } \\
\text { Mean (M) }\end{array}$ & $\begin{array}{c}\text { Standard Deviation } \\
(\text { STDEV })\end{array}$ & $\begin{array}{c}\text { T Statistics } \\
(|\mathrm{O} / \mathrm{STDEV}|)\end{array}$ & P Values \\
\hline SQ -> CS & 0.649 & 0.674 & 0.083 & 7.824 & 0.000 \\
\hline
\end{tabular}

is significant on students' satisfaction. Hence, the hypothesis $(\mathrm{H})$ is supportable.

\subsection{Discussion}

The objective of this study is to test and explain the influence of service quality (SQ) on student satisfaction as a customer of Hotel Management Department at Dili Institute of Technology (DIT), Timor-Leste. The results of this research show that service quality has a positive and significant influence on student's satisfaction.

In this research, service quality focuses more on serving students on time, lecturers teach well according to their roles, the academic department consistently serves students well and students feel comfortable to study environment. That's why there is a positive impact on student satisfaction on facilities, tuition fees, service, and no discrimination policies. This indicates that students put more emphasis on intangible parts as the first option to increase their satisfaction compared to tangible parts such as facilities and equipment. This research confirmed previous studies which showed that service quality has a significant influence on customer satisfaction (Keshavarz and Jamshidi, 2018; Saldanha et al., 2018; Flores, Saldanha and Vong, 2020; Borishade et al., 2021).

\section{Conclusion and Implication}

Service quality and customer satisfaction are wellestablished variables in the marketing studies such as the hotel industry, and higher education institutions. However, there have not been many studies in Timor-Leste, especially in the area of higher education. This study is related to the hotel department because the number of students is declining, but lecturers' competence and facilities are improving.

The inferential results show that service quality has a positive and significant influence on customer satisfaction. This means that the level of customer satisfaction rises when the service quality is good. The factors that support the significant relationship between the two variables are lecturers' competence; discrimination study environment and good teaching facilities. This means that Hotel Management Department continues to improve their service quality to raise the level of students' satisfaction and loyalty.

\section{Limitation and Future Research}

The results of this research show that service quality positively and significantly influences customer satisfaction. Nevertheless, this research has some limitations such as: (1) This study was only applied for Hotel Management Department students at DIT with a total population of 71 . The quantity of samples is relatively small in number. Therefore, future research needs to increase the number of samples in order to get better results. (2) This study only used a questionnaire as a data collection instrument which was difficult to confirm why students preferably choose the non-tangible dimension compared to tangible. Thus, the next research needs data collection instruments such as in-depth interviews, focus group discussion, and observation to know more about students' preferences and realities that they obtained. (3) The inferential data shows that the tangible dimension is not valid and reliable to measure the service quality. Hence, this dimension was deleted from the inferential analysis according to Hair et al. (2014). Therefore, the next research needs to develop indicators in proper tangible dimensions to measure the service quality.

\section{References}

Annamdevula, S. and Bellamkonda, Raja Shekkar (2016) 'Effect of student perceived service quality on student satisfaction, loyalty and motivation in Indian universities Development of HiEduQual', Journal of Modelling in Management, 11(2), pp. 488-517.

Annamdevula, S. and Bellamkonda, Raja Shekhar (2016) 'The effects of service quality on student loyalty: the mediating role of student satisfaction', Journal of Modelling in Management, 11(2), pp. 446-462.

Babin, B. J., James, K.W., Camp, K, Jones, R.P., Parker, J.M. (2019) 'Pursuing personal constructs through quality, value, and satisfaction', Journal of Retailing and Consumer Services, 51(April), pp. 33-41.

Boonlertvanich, K. (2019) 'Service quality, satisfaction, trust, and loyalty: the moderating role of main-bank and wealth status', International Journal of Bank Marketing, 37(1), pp. 278-302.

Borishade, T. T., Ogunnaike, O.O., Salau, O., Motilewa, B.D., Dirisu, J.I. (2021) 'Assessing the relationship among service quality, student satisfaction and loyalty: the Nigerian higher education experience', Heliyon, e07590.

Carranza, R., Díaz, E. and Martín-Consuegra, D. (2018) ‘The 
influence of quality on satisfaction and customer loyalty with an importance-performance map analysis: Exploring the mediating role of trust', Journal of Hospitality and Tourism Technology, 9(3), pp. 380-396.

Chen, S. C. (2012) 'The customer satisfaction-loyalty relation in an interactive e-service setting: The mediators', Journal of Retailing and Consumer Services, 19(2), pp. 202210.

DeSarbo,.W.S., Benedetto, C.A.D., and Song, M. ( 2015) ' A heterogeneous resource based view for exploring relationships between form performance and capabilities': Article in Journal of Modeling in Management, pp.104.

Dominici, G. and Guzzo, R. (2010) 'Customer Satisfaction in the Hotel Industry: A Case Study from Sicily', International Journal of Marketing Studies, 2(2), pp. 2-12.

Durga Ranabhat (2018) Customer Loyalty in Business, Centria University of Applied Science.

Elisabeth, D.R.,Nasir, A., and Suyono, J.(2019) 'The Effect of Service Quality on Customer Satisfaction at Koperasi Karyawan PT. Lotus Indah TextileIndustry. International Journal of Enrepreneurship and Business Development, pp 173. ISN:2597-4785,

Famiyeh, S., Kwarteng, A. and Asante-Darko, D. (2018) 'Service quality, customer satisfaction and loyalty in automobile maintenance services: Evidence from a developing country', Journal of Quality in Maintenance Engineering, 24(3), pp. 262-279.

Flores, A. F., Saldanha, de S. S. and Vong, M. F. (2020) 'The effect of customer satisfaction Mediation on the relationship between service quality and customer loyalty', Timor-Leste Journal of Business and Management, 2(1), pp. $56-65$

Gilbert, G. R. and Cleopatra Veloutsou (2016) 'A Cross Industry of Customer Satisfaction', Journal Service Maeketing, 1(1), p. 9.

Hair, J., Hollingsworth, C.L., Randolph, A.B., Chong, A.Y.L (2017) 'An updated and expanded assessment of PLS-SEM in information systems research', Industrial Management \& Data Systems, 117(3), pp. 442-458.

Hair, J. F., Sarstedt, M., Hopkins, L., Kuppelwieser, V.G. (2014) 'Partial least squares structural equation modeling (PLS-SEM)', European Business Review, 26(2), pp. 106121.

Henseler, J., Ringle, C. M. and Sarstedt, M. (2015) 'A new criterion for assessing discriminant validity in variance- based structural equation modeling', Journal of the Academy of Marketing Science, 43(1), pp. 115-135.

Jiang, H. and Zhang, Y. (2016) 'An investigation of service quality, customer satisfaction and loyalty in China's airline market', Journal of Air Transport Management, 57, pp. 8088 .

Kaura, V., Prasad, C. S. D. and Sharma, S. (2015) 'Service quality, service convenience, price and fairness, customer loyalty, and the mediating role of customer satisfaction', Marketing Intelligence and Planning, 33(4), pp. 404-422.

Keshavarz, Y. and Jamshidi, D. (2018) 'Service quality evaluation and the mediating role of perceived value and customer satisfaction in customer loyalty', International Journal of Tourism Cities, 4(2), pp. 220-244.

Khoo, S., Ha, H. and McGregor, S. L. T. (2017) 'Service quality and student/customer satisfaction in the private tertiary education sector in Singapore', International Journal of Educational Management, 31(4), pp. 430-444.

Lam, R. and Burton, S. (2006) 'SME banking loyalty (and disloyalty): A qualitative study in Hong Kong', International Journal of Bank Marketing, 24(1), p. 17.

Mahmudi, R.K., and Abdoli, E.,(2016) 'The Effect of Service Quality on Customer Loyalty: A Case Study on Clients of Asia Insurance Co.,Miandoab, Iran', International Journal of Humanities and Cultural Studies, pp.790-791.

Mbama, C. I. and Ezepue, P. O. (2018) 'Digital banking, customer experience and bank financial performance: UK customers' perceptions', International Journal of Bank Marketing, 36(2), pp. 230-255.

Miranda, S., Tavares, P. and Queiró, R. (2018) 'Perceived service quality and customer satisfaction: A fuzzy set QCA approach in the railway sector', Journal of Business Research, 89(July 2017), pp. 371-377.

Özkan, P., Süer, S., Keser, İ.K., Kocakoç, İ. D. (2019) 'The effect of service quality and customer satisfaction on customer loyalty: The mediation of perceived value of services, corporate image, and corporate reputation', International Journal of Bank Marketing. doi: 10.1108/IJBM-03-2019-0096.

Parasuraman, A., Zeithaml, V. A. . and Berry, L. L. (1988) 'SERVQUAL: a Multiple-item Scale for Measuring Consumer Perceptions of Service Quality', Retailing: critical, 64(1), pp. 12-40.

Parasuraman, A., Zeithaml, V. A. and Berry, L. L. (1994) 
'Alternative scales for measuring service quality: A comparative assessment based on psychometric and diagnostic criteria', Journal of Retailing, 70(3), pp. 201-230.

Porter, M. E. (1980). Competitive strategy: Techniques for analyzing industries and companies. In New York. The Free Press.

Porter, M. E. (1985). Competitive Advantage - Creating and Sustaining Superior Performance. In New York: FreePress. The Free Press.

Rompo, N.(2015) 'The Study of the Difference in Performance Measurement System in Different Industries.Thammasat University, Journal of Strategic Innovation and Sustainability. Vol10(2), pp.59.

Rua, S., Saldanha, E. de S. and Amaral, A. M. (2020) 'Examining the Relationships among Product Quality, Customer Satisfaction and Loyalty in the Bamboo Institute, Dili, Timor-Leste., Timor-Leste Journal of Busi, 2(1), pp. 33-44.

Saldanha, E. de S., Rahyuda, I.K., Yasa, N.N.K., Sukkatmadja, I.P.G. (2018) 'The Role of Business Strategy in Mediating the Relationship Between Industrial Competition and Performances: A Study in the Higher Education Industry in Timor-Leste', European Jorunal of Business and Management, 10(8), pp. 152-172.

Saldanha, E. de S., Rahyuda, I. K., Yasa, N.N.K., Sukkatmadja, I.P.G. (2019) 'Industrial Competition, Hybrid Strategy and Industrial Performance: Study in Higher Education Industry in Timor-Leste', Journal of Engineering and Applied Sciences, 14(8), pp. 2456-2464.

Sangpikul, A. (2018) 'The effects of travel experience dimensions on tourist satisfaction and destination loyalty: the case of an island destination', International Journal of Culture, Tourism, and Hospitality Research, 12(1), pp. 106123.
Farooq, M.S.,Salam, M.,Fayole, A., Jaafar, N., and Ayup, K.(2018) 'Impact of service quality on customer satisfaction in Malaysia airlines : A PLS-SEM approach', Journal of Air Transport Management, 67(December 2017), pp. 2017 2019.

Spyridou, A. (2017) 'Perceived Service Quality and Customer Revisiting Intention: The Case of "all you can eat" Asian Restaurants in Southern Taiwan', MPRA Paper, (46733), p. 10.

Sriyalatha, K. and Appuhamilage, M. (2019) 'The impact of loyalty on the student satisfaction in higher education A structural equation modeling analysis', Higher Education Evaluation and Developmen. doi: 10.1108/HEED-01-20190003.

Stavkova, J., Stejkal, L. and Toufarova, Z. (2008) 'Factors influencing consumer behaviour', (6), p. 9 .

Subrahmanyam, A. (2017) 'Relationship between service quality, satisfaction, motivation and loyalty: A multidimensional perspective', Quality Assurance in Education, 25(2), pp. 171-188.

Tongshineen, D. N., Alamai, M.M., and Chinyere, U.I. (2018) 'assessing the Efeect of Quality Service of Small Hotels on Customers Satisfaction in Bauchi Nigeria, IOSR Journal of Humanities and Social Science(IORS-JHSS). DOI:10.9790/0837-2303056371, pp.63.

Wilkins, H., Merrilees, B. and Herington, C. (2007) 'Towards an Understanding of Total Service Quality in Hotels', International Journal of Hospitality Management, 26(4), p. 14. 


\section{Appendix}

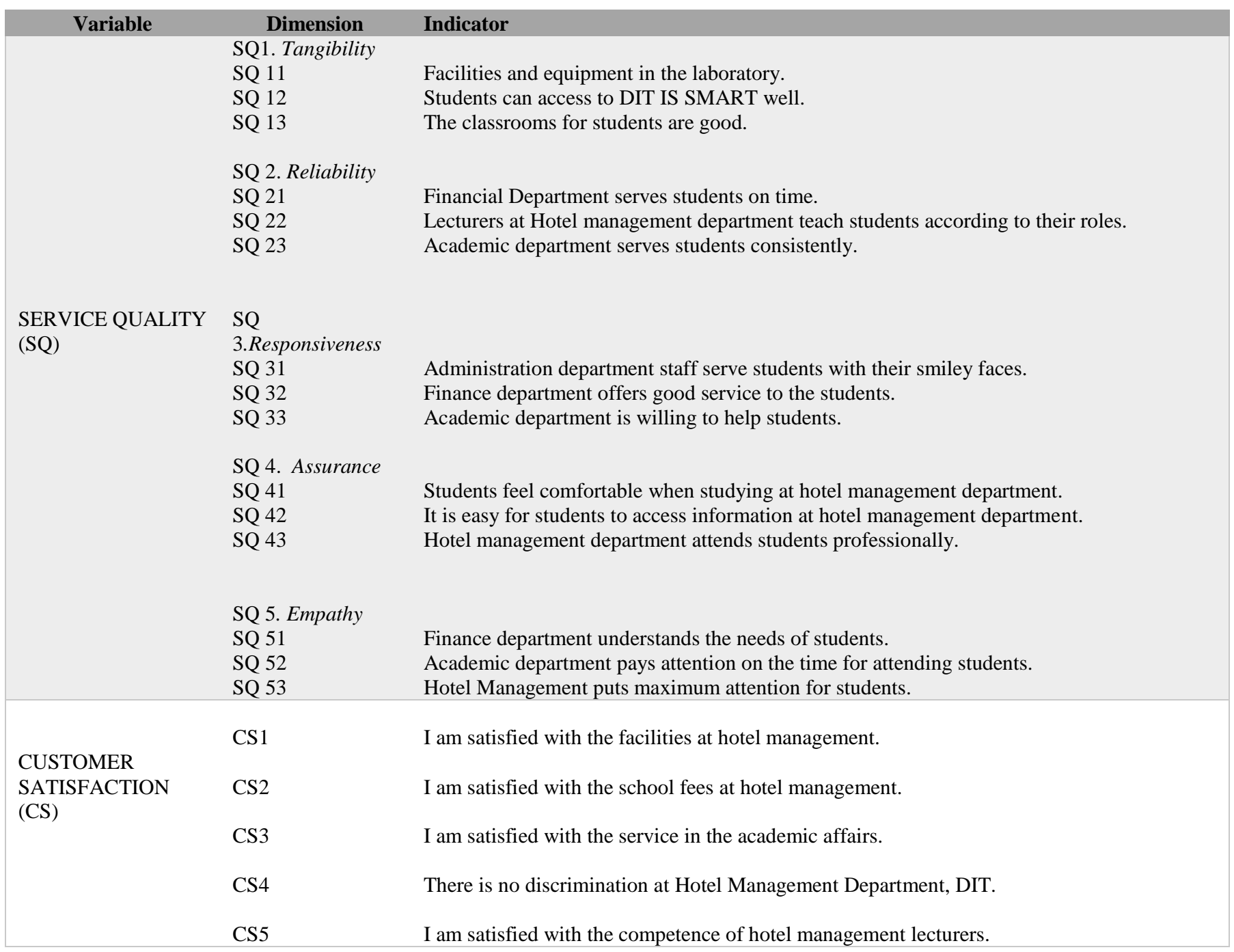

